Seloka: Jurnal Pendidikan Bahasa dan Sastra Indonesia
$9(3)(2020): 247-253$
UNNES
https://journal.unnes.ac.id/sju/index.php/seloka

\title{
Phonology of Malay Language in Karimun Regency, Riau Islands
}

\author{
Hariani Kustiah $^{1 凶}$, Ida Zulaeha ${ }^{2}$, Hari Bakti Mardikantoro ${ }^{2}$ \\ ${ }^{1}$ Univeristas Maritim Raja Ali Haji, Indonesia \\ ${ }^{2}$ Universitas Negeri Semarang, Indonesia
}

\begin{abstract}
Article Info
History Articles

Received:

August 2020

Accepted:

Oktober 2020

Published:

December 2020

Keywords: phonology, vowel, consonant, phonological differences (distance)

Abstract

The Malay language that is spoken in Karimun Regency is a unique and diverse language. The uniqueness and diversity of the Malay language lies in phonology. The purpose of this study is to analyze the phonological variations and phonological differences of the Malay language in Karimun Regency, Riau Islands. The focused places of this study are located in three districts, namely Karimun District, West-Kundur District and Moro District. This study uses a dialect geography approach and qualitative descriptive. The data were collected by using the listening that is followed by simak libat cakap method, recording, and taking notes technique. The results showed that the Karimun Malay language has phonological variations in the form of vowel and consonant variations. Phonological variations happen due to geographic locations between different observation areas and they are obliviously limited to other regions. The phonological differences of the Karimun Malay language in the three observation places are categorized in speech difference. The results of data calculated is analyzed the phonological dialectometric method of Karimun Malay language in the three observation places is $4-7 \%$ in percentage.
\end{abstract}

\footnotetext{
$\bowtie$ Correspondence address:

Sawang, Kundur Barat, Kabupaten Karimun , Kepulauan Riau (29662).

E-mail: harianiyani27@gmail.com
} 


\section{INTRODUCTION}

Language is the most common symbol of nationality and it is seen as the main physical sign of a group's identity (Aman, 2009). Malay language is the mother tongue of the Austronesian language, with around 20 million speakers in Indonesia (Astar, 2013).

Malay language of Riau Islands is the parent language of Indonesian language. This is stated by Malik (2013), that Indonesian comes from the Malay language of the Riau Islands. This research is motivated by the discovery of phonological variations on the form of vowel and consonant variations in the Malay language used in Karimun Regency, Riau Islands Province, especially in Karimun, West-Kundur and Moro.

The phonological variations of the Malay language spoken by the society in Karimun, West Kundur and Moro are caused by each observation area which is directly adjacent to other countries, other provinces, and other islands. This opinion is supported by Sultan and Jamil (2019) who stated that language variations come up due to the geographical location that is bordering with other areas; and it is caused by rivers, mountains and forests. Harahap (2014) also states that there are several factors causing the emergence of language variations, namely geographical factors, social position factors and language situation factors.

In linguistics, the field of phonological study is about the sounds of language. This opinion is supported by Chaer (2009) which states that phonology is a field of linguistic studies that learn and discuss about sounds of language that is produced by human's speech tools. Furthermore, in Arman's research (2013) states that phonology is a science that analyze the differences in utterance.

From a dialectological point of view, sound changes (vowels and consonants) are related with two aspects, namely linguistic aspects and geographical aspects. In linguistics, the occurrence of sound changes is caused by certain environmental factors. Meanwhile in geographically, the change of sound occurs due to the spread of sound that occurs in the same observation area (Zulaeha, 2016).

To determine the status of a variant into the language level, whether the language belongs to the same or different languages, sub-dialects, or that language belongs to different speech groups; it can be analyzed by using the dialectometric method. Syahrir (2018) states that dialectometric is a statistical measure used to see how far the differences and similarities or variations are found in the areas studied by comparing a number of materials collected from that place. In addition, Mahsun (in Sanjoko, 2016) also emphasized that the most relevant method in dialectology research is the dialectometric method.

Research of the phonology of the Malay language in Karimun Regency, Riau Islands has never been carried out. The problem revealed in this study is there are variations in the phonology of the Malay language that occur due to differences in the geographic location of each observation area. The objectives of this study were 1) to analyze vowel variations 2) to analyze consonant variations and 3) to analyze phonological differences between the Malay language in Karimun Regency, Riau Islands.

This study is also related with the previous research which also discusses the study of language variation in phonology that were conducted by Hastuti (2018), Afidah (2019), Antono (2019), Ridwan (2020), Zulaeha (2019), and Zulaeha (2020).

In practical terms, this research is expected to be useful for the regional language development and guidance institutions of the Riau Islands; it can provide information on the phonological variations of the Malay language in Karimun Regency, especially in Karimun, West-Kundur and Moro. It is because there has been no scientific research evidence that states the language differences of Malay language in Karimun Regency.

\section{METHODS}

There are two approaches in this research, namely a theoretical approach and a 
methodological approach. Theoretically, this study uses a dialect geography approach, namely the study of language variations / uniqueness based on regional or geographic elements. Meanwhile, the methodological approach used is a qualitative descriptive approach. The data of this study is the vocabularies of the Malay language.

The data source of this study came from 6 informants at three observation points (TP/Titik Pengamatan), who were selected based on the criteria that is putted forward by Nother (1991) and Fernandez (1992). This study used an instrument contains of a list 335 questions form. The research data were collected using the field pupuan method or field research by using questionnaire and the listening method with the proficient engaging listening technique or simak libat cakap, the recording technique, and the note-taking technique.

\section{RESULTS AND DISCUSSION}

The discussion of the results of phonology of the Malay language research in Karimun Regency, Riau Islands includes vowel variations, variations in consonants and phonological differences.

\section{Vowel Variations}

Based on the data obtained, it was found that variations in the $B M K$ vowel sound were used in the three $T P$, namely variations of the sound

$$
\begin{aligned}
& \text { [i] } \sim[\varepsilon],[\mathrm{a}] \sim[\varnothing],[\mathrm{u}] \sim[\text { [ə], [a] [o] } \\
& {[ə] \sim[\varnothing],[\mathrm{a}] \sim[\mathrm{\partial}],[\partial] \sim[\mathrm{a}],[\mathrm{i}] \sim[\mathrm{e}],} \\
& {[\mathrm{a}] \sim[\mathrm{u}],[\mathrm{\varepsilon}] \sim[\mathrm{o}],[\mathrm{o}] \sim[\mathrm{u}],[\mathrm{u}] \sim[\mathrm{o}],} \\
& {[\varnothing] \sim[\mathrm{u}],[\varnothing] \sim[ə],[\varepsilon] \sim[\mathrm{a}],[ə] \sim[\supset],} \\
& \text { and }[ə] \sim[0] \text {. }
\end{aligned}
$$
'adik / ' [adik] 'younger' becomes [adek]. The sound [i] tends to be spoken by all speakers in TP-1, while the sound $[\varepsilon]$ is used in TP-2 and TP-3.

The variation $[\mathrm{a}] \sim[\varnothing]$ is found in the gloss "father of father / mother" [atok] becomes [tok]. The sound [a] tends to be used in TP-1, while the sound [ø] is used in TP-1 and TP-2.

The variation $[\mathrm{u}] \sim[\mathrm{\partial}]$ is found in the gloss of 'durian' [durian] to [dərian]. The sound [u] tends to be spoken by all speakers in TP-1, while the sound [ə] is used in TP-2 and TP-3.

Variations [a] $\sim$ [o] are found in gloss 'butt / pantat' [pantat] becomes [pontot]. The sound [a] is spoken by all speakers in TP-1, while the sound [o] is used in TP-2 and TP-3.

The variation [ə] $\sim[\varnothing]$ is found in the gloss 'ibu' [əmak] becomes [mak]. The sound [ə] tends to be spoken by all speakers on TP-1, while the sound [ø] is used in TP-3.

Variations [a] [ə] are found in the gloss of 'pineapple' 'nanas' [nanas] to [nonas]. The sound [a] tends to be used in TP-1, while the sound [ə] is used in TP-2 and TP-3.

The variation [ə] $\sim$ [a] is found in the gloss "designation for middle child" [udə] becomes [uda]. The sound [ə] is spoken by all speakers in TP-2, while the sound [a] is used in TP-3.

The variation [i] $\sim$ [e] is found in the gloss 'masjid' [məsjid] becomes [məsjed]. The sound [i] tends to be spoken by all speakers in TP-1, while the sound [e] is used in TP-2 and TP-3.

The variation $[\mathrm{a}] \sim[\mathrm{u}]$ is found in the gloss "hit / memukul" [ləpak] to be [ləpuk]. The sound [a] is spoken by all speakers in TP-2, while the sound [u] is used in TP-3.

The variation of $[\varepsilon] \sim[0]$ is found in the gloss "chatter / cerewet" [mərepet] to [məropet]. The sound $[\varepsilon]$ is spoken by all speakers in TP-1, while the sound [o] tends to be used in TP-2 and TP-3.

The variation $[\mathrm{o}] \sim[\mathrm{u}]$ is found in the gloss "veil / jilbab" [tudon] becomes [tuduy]. The sound [o] tends to be spoken by all speakers in TP-2, while the sound [u] is used in TP-3.

The variation $[\mathrm{u}] \sim[\mathrm{o}]$ is found in the gloss "fat / gemuk " [fat] becomes [fat]. The sound $[\mathrm{u}]$ tends to be used in TP-1 and the sound [o] is used in TP-2 and TP-2.

The variation $[\varnothing] \sim[u]$ is found in the gloss of 'father's / mother's younger brother', namely [pak / mak su] to [pak / mak usu]. The sound [ø] tends to be spoken by all speakers in 
TP-1, while the sound $[\mathrm{u}]$ is used in TP- 2 and TP-3.

The variation $[\varnothing] \sim[\ominus]$ is found in the gloss "port / pelabuhan" [plantar] to [pəlanta]. The sound $[\varnothing]$ tends to be spoken by all speakers in TP-1 and TP-2, while the sound [ə] is used in TP-3.

The variation $[\varepsilon] \sim[a]$ is found in the gloss of 'pretend / berpura-pura' that is [ecekec\&k] to [ecak-ecak]. The sound $[\varepsilon]$ tends to be spoken by all speakers in TP-2, while the vowel sound $[\mathrm{a}]$ is used in TP-3.

The variation [ə] $\sim[0]$ is found in the gloss "flower / bunga " [buyə] becomes [buyo]. The sound [ə] tends to be spoken by all speakers in TP-1 and TP-3, while the sound [0] is used in TP-2.

The variation $[ə] \sim[0]$ is found in gloss 'two / dua' [due] to [duo]. The sound [ə] tends to be spoken by all speakers in TP-1 and TP-3, while the sound [o] is used in TP-2.

\section{Consonant Variation}

There are variations of consonant sounds in BMK including variations of sounds $[\mathrm{k}] \sim[\mathrm{h}]$, $[\mathrm{h}] \sim[\mathrm{k}],[\mathrm{h}] \sim[\mathrm{m}]$, $[\mathrm{s}] \sim[\mathrm{c}],[\mathrm{y}] \sim[\mathrm{r}],[\mathrm{b}] \sim[\varnothing],[\mathrm{h}] \sim[\varnothing]$, $[\mathrm{j}] \sim[\mathrm{s}],[\mathrm{r}] \sim[\varnothing],[\varnothing] \sim[\mathrm{k}],[\varnothing] \sim[?]$, $[\varnothing] \sim[\mathrm{r}]$ and $[\mathrm{m}] \sim[\mathrm{r}]$.

The variation $[\mathrm{k}] \sim[\mathrm{h}]$ is found in the gloss of 'the $5^{\text {th }}$ child' [andak] being [andah]. The sound $[\mathrm{k}]$ tends to be spoken by all speakers in TP-1 and TP-2, while the sound $[\mathrm{h}]$ is spoken in TP-3.

The variation $[\mathrm{h}] \sim[\mathrm{k}]$ is found in the gloss of "cupboard" [gəroboh] to [gərobok]. The sound $[\mathrm{h}]$ tends to be spoken by all speakers on TP-1, while the sound [k] is spoken in TP-2.

The variation $[\mathrm{h}] \sim[\mathrm{m}]$ is found in the gloss "stabbing" [tujah] becomes [tujam]. The sound $[\mathrm{h}]$ tends to be spoken by all speakers in TP-1, while the sound [m] is used in TP-2.

The variation $[\mathrm{c}] \sim[\mathrm{s}]$ is found in the gloss "last child" [usu] becomes [ucu]. The sound [c] tends to be spoken by all speakers in TP-1 while the sound [s] is spoken in TP-2.
The variation $[\mathrm{y}] \sim[\mathrm{r}]$ is found on the gloss of 'necklace' [yantay] to be [rantai]. The sound $[\mathrm{\gamma}]$ tends to be spoken by all speakers in TP- 1 and TP-3, while the sound [r] is spoken in TP-2.

Variations $[b] \sim[\varnothing]$ are found on the gloss 'tomorrow / besok' [besok] to [esok]. The sound [b] tends to be spoken by all speakers in TP-1, while the sound [ø] tends to be used in TP-2 and TP-3.

The variation $[\mathrm{h}] \sim[\varnothing]$ is found in the gloss "ginger / jahe " [haliyə] becomes [aliyə]. The sound $[\mathrm{h}]$ tends to be spoken by all speakers on TP-1, while [ø] is more likely to be omitted in TP-2 and TP-3.

The variation $[r] \sim[\varnothing]$ was found to be 'egg / telur' [egg] to [telo]. The [r] sound tends to be spoken by all speakers in TP-1, while the [ø] sound in TP-2 and TP-3.

The variation $[\varnothing] \sim[\mathrm{k}]$ is found in the gloss "rice / nasi" [nasi] to [nasik]. The sound [ø] tends to be spoken by all speakers in TP-1, while the sound $[\mathrm{k}]$ tends to be used in TP-2 and TP-3.

The variation $[\varnothing] \sim[?]$ is found in the gloss "saliva" [lio] becomes [lio?]. The [ø] sound tends to be used in TP-2, while the sound [?] Tends to be used in TP-3.

The variation $[\varnothing] \sim[\mathrm{r}]$ is found on the gloss of 'window cover' [laysi] to [laysir]. The sound $[\varnothing]$ tends to be spoken by all speakers in TP- 1 and TP-2, whereas the sound $[\mathrm{r}]$ is used in TP-3.

The variation $[\mathrm{m}] \sim[\mathrm{r}]$ is found in the gloss "grumpy" [pəmənis] becomes [pərənis]. The sound $[\mathrm{m}]$ was spoken by all speakers in TP1 while the sound [r] was spoken in TP-3.

Variations in both vowels and consonants in the Karimun Malay language occur because of the different geographical locations between the TPs, which are directly adjacent to other provinces and countries. The TP-1 is directly adjacent to Malaysia, TP-2 borders with Riau Province and TP-3 is on a remote island geographically.

The effect of language use from other countries and provinces adjacent directly to the TP can be proven by the some facts of variations in the vowel sound [i] on TP-1 and variations in 
the vowel sound [o] on TP-2. This finding is in line with findings in Ubaidillah and Norlaili's (2020) research on the Malay language of Riau Province which state that the word "ear / telinga " in Indonesian is pronounced as [təlino] in the Bagan Siapi-api area of Riau Province.

\section{Phonological Difference (Distance)}

The results of calculating phonological variations using the dialectomy method between TP-1 and TP-2 obtained a difference in 5.6\% percentage. Furthermore, the recalculation was carried out on TP-1 which is compared to TP-3 obtained a difference in $6.2 \%$ percentage. Meanwhile, the calculation of the difference between TP-2 and TP-3 obtained is 5.6\% in percentage. By looking at the dialectometric scale, the phonological difference between TP-1, TP-2 and TP-3 is included in the speech difference category because all three are in the percentage of $4-7 \%$.

By considering of the administrative map, the geographical proximity is the cause between TP-1 and TP-2; hence, TP-2 and TP-3 having the same percentage. Based on the administrative map, TP-2 is in the middle between TP-1 and TP-3, so according to the distance TP-2 is close to TP-1 and TP-3. Therefore, this causes an equation for the results of calculating the different distances on this TP.

Meanwhile, the ratio between TP-1 and TP-3 had the highest percentage difference, which is $6.2 \%$. The high percentage of phonological difference between TP-1 and TP-3 was caused by the location of the two TP that were far apart. By looking at this finding, it can be concluded that there are phonological variations in both vowel and consonant variations, it can be seen from how far the distance of the TP is; there are more variations are found. However, the closer geographic location of the TP, the fewer phonological variants are found.

\section{CONCLUSION}

The phonological variations of the Malay language in Karimun Regency, Riau Islands, which are used at three observation places in this study are vowel variations and consonant variations. Based on phonological difference (distances), the phonological variations of Malay language found in TP-1, TP-2 and TP-3 are included in the speech-difference category.

\section{REFERENCES}

Afidah, A. U., dan Mardikantoro, H. B. (2019). Variasi Fonologi dan Leksikon Bahasa Jawa di Kabupaten Cilacap (Kajian) Geografi Dialek di Perbatasan JawaSunda. Jurnal Sastra Indonesia, 8 (1), 78-87 http://journal.unnes.ac.id/sju/index.php /jsi

Aman, I., \& Mustaffa, R. (2009). Social Variation Of Malay Language In Kuching, Sarawak, Malaysia: A Study On Accent, Identity And Integration. GEMA Online ${ }^{\circledR}$ Journal of Language Studies, 9(1), 63-76.

Antono, A., Zulaeha, I., \& Baehaqie, I. (2019). Pemertahanan Fonologis dan Leksikal Bahasa Jawa di Kabupaten Wonogiri: Kajian Geografi Dialek. Jurnal Sastra Indonesia,8(1), 23-32.

Arman., Suharyanto., \& Panggabean, N. (2013). Fonologi Bahasa Biyekwok. Kandai, 9(1), 9-23.

Astar, H. (2013). Vowel Variation Of Malay Language In The Land Of Riau And The Islands Of Riau. Jurnal Gramatika, 1(2), 93-102.

Chaer. A. (2009). Fonologi. Jakarta: Rineka Cipta.

Fernandez, I.Y. (1992). Sosiodialektologi Diakronis. Laporan Praktik Studi Lapangan Mahasiswa S2 UGM Yogyakarta.

Harahap, E. M. (2014). Variasi Fonologi dan Leksikon Dialek Angkola Desa Sialagundi Di Desa Aek Garugur Kabupaten Tapanuli Selatan. Jurnal Metamorfosa, 2(2), 31-52.

Hastuti, A. P., Zulaeha, I., \& Baehaqie, I. (2018). Pemakaian Fonologi dan Leksikon Bahasa Jawa: Studi 
Sosiodialektologi Di Kabupaten Batang. Jurnal Sastra Indonesia 7 (1), 7-19.

Nother, B. (1991). Tinjauan Sinkronis dan Diakronis Dialek-Dialek Bahasa Jawa di Jawa Barat dan Jawa Tengah (Bagian Barat)". Diskusi Bahasa Asia TenggaraPasifik. Yogyakarta: PSI fakultas sastra UGM.

Ridwan., Maricar, F., Mulae, S. O., \& Asriyani, S. (2020). Phonological Variation Of Taliabu Language Dialects. Retorika: Jurnal Bahasa, Sastra, dan Pengajarannya, 13(1), 156-163.

Sanjoko, Y., Suharyanto., \& Marawuri, E. (2016). Dialectology Of Biak Language. Journal Metalingua, 14 (1), 131-144.

Sultan, F.M., \& Jamil, A.I. (2019). The Variation of Malay Lexical Dialect In Kedah: A Geolinguistics Study. Geografia Online $^{T M}$ Malaysian Journal of Society and Space, 15(4), 16-29.

Syahrir, E. (2018). Variasi Leksikal Tiga Isolek dalam Keluarga Bahasa Melayu Riau. Journal Madah, 8(2), 195-210.

Ubaidillah \& Norlaili. (2020). Inovasi dan Retensi Fonologis Proto Bahasa Melayu pada Bahasa Melayu Riau Dialek Pesisir. Ranah: Jurnal Kajian Bahasa, 9(1), 141159.

Zulaeha, I. (2016). Teori Dialektologi, Dialek Sosial dan Regional. Semarang: Unnes Press.

Zulaeha, I., Baehaqie, I., Fitriyaningsih., Rosyadi, D., \& Prihatmini, E. (2019). Comparison of Java Language Lectics with Sunda Language in Larangan District, Brebes Regency. Advances in Social Science, Education and Humanities Research: International Conference on Science and Education and Technology (ISET 2019). 615-618.

Zulaeha, I., Farida, L.A., \& Rokhman, F. (2020). Phonological and Lexical Shifts Javanese Dialect in Diachronic Studies. Advances in Social Science, Education and Humanities Research: Proceedings of the 1st Progress in Social Science, Humanities and Education Research
Symposium (PSSHERS 2019). 11371144.

Aman, I., \& Mustaffa, R. (2009). Social Variation Of Malay Language In Kuching, Sarawak, Malaysia: A Study On Accent, Identity And Integration. GEMA Online ${ }^{\circledR}$ Journal of Language Studies, 9(1), 63-76.

Antono, A., Zulaeha, I., \& Baehaqie, I. (2019). Pemertahanan Fonologis dan Leksikal Bahasa Jawa di Kabupaten Wonogiri: Kajian Geografi Dialek. Jurnal Sastra Indonesia, 8(1), 23-32.

Arman., Suharyanto., \& Panggabean, N. (2013). Fonologi Bahasa Biyekwok. Kandai, 9(1), 9-23.

Astar, H. (2013). Vowel Variation Of Malay Language In The Land Of Riau And The Islands Of Riau. Jurnal Gramatika, 1(2), 93-102.

Chaer. A. (2009). Fonologi. Jakarta: Rineka Cipta.

Fernandez, I.Y. (1992). Sosiodialektologi Diakronis. Laporan Praktik Studi Lapangan Mahasiswa S2 UGM Yogyakarta.

Harahap, E. M. (2014). Variasi Fonologi dan Leksikon Dialek Angkola Desa Sialagundi Di Desa Aek Garugur Kabupaten Tapanuli Selatan. Jurnal Metamorfosa, 2(2), 31-52.

Hastuti, A. P., Zulaeha, I., \& Baehaqie, I. (2018). Pemakaian Fonologi dan Leksikon Bahasa Jawa: Studi Sosiodialektologi Di Kabupaten Batang. Jurnal Sastra Indonesia 7 (1), 7-19.

Nother, B. (1991). Tinjauan Sinkronis dan Diakronis Dialek-Dialek Bahasa Jawa di Jawa Barat dan Jawa Tengah (Bagian Barat)". Diskusi Bahasa Asia TenggaraPasifik. Yogyakarta: PSI fakultas sastra UGM.

Ridwan., Maricar, F., Mulae, S. O., \& Asriyani, S. (2020). Phonological Variation Of Taliabu Language Dialects. Retorika: Jurnal Bahasa, Sastra, dan Pengajarannya, 13(1), 156-163. 
Sanjoko, Y., Suharyanto., \& Marawuri, E. (2016). Dialectology Of Biak Language. Journal Metalingua, 14 (1), 131-144.

Sultan, F.M., \& Jamil, A.I. (2019). The Variation of Malay Lexical Dialect In Kedah: A Geolinguistics Study. Geografia Online $^{T M}$ Malaysian Journal of Society and Space, 15(4), 16-29.

Syahrir, E. (2018). Variasi Leksikal Tiga Isolek dalam Keluarga Bahasa Melayu Riau. Journal Madah, 8(2), 195-210.

Ubaidillah \& Norlaili. (2020). Inovasi dan Retensi Fonologis Proto Bahasa Melayu pada Bahasa Melayu Riau Dialek Pesisir. Ranah: Jurnal Kajian Bahasa, 9(1), 141159.

Zulaeha, I. (2016). Teori Dialektologi, Dialek Sosial dan Regional. Semarang: Unnes Press.
Zulaeha, I., Baehaqie, I., Fitriyaningsih., Rosyadi, D., \& Prihatmini, E. (2019). Comparison of Java Language Lectics with Sunda Language in Larangan District, Brebes Regency. Advances in Social Science, Education and Humanities Research: International Conference on Science and Education and Technology (ISET 2019). 615-618.

Zulaeha, I., Farida, L.A., \& Rokhman, F. (2020). Phonological and Lexical Shifts Javanese Dialect in Diachronic Studies. Advances in Social Science, Education and Humanities Research: Proceedings of the 1st Progress in Social Science, Humanities and Education Research Symposium (PSSHERS 2019). 11371144. 